\title{
Report \\ Social Vulnerability and Ecological Fragility: Building Bridges between Social and Natural Sciences Using the Irish Potato Famine as a Case Study
}

\author{
Evan D. G. Fraser
}

ABSTRACT. Between 1845 and 1850, a potato blight triggered a famine that killed or displaced 25\% of the Irish population. Aside from its historical and cultural significance, the Irish Potato Famine illustrates how social and economic forces can create vulnerability to environmental disturbance. Therefore, studying the famine contributes to the on-going academic debate on theories to combine social and environmental data. This paper explores the conditions leading to the Irish famine using the "Entitlement" framework of Sen (1980) and the "Panarchy" model proposed by Gunderson and Holling (2002). Entitlement theory allows us to better understand how community food security may become vulnerable over time as different social and economic forces eliminate or restrict avenues to obtain food. In Ireland, a host of economic, demographic, and social pressures marked the decades leading to the famine and meant that the Irish peasantry had no food options when the potato crop failed. Panarchy provides a way of characterizing ecological systems that are vulnerable to disruptions. The agroecosystem that developed in Ireland prior to the famine had characteristics typical of vulnerable environments: fields were close together, biodiversity was low, and a large amount of biomass made this ecosystem attractive to opportunistic pests. Neither framework, however, provides an adequate way of examining the totality of humanenvironmental relations. By combining entitlements with panarchy, we can explore both the social and environmental characteristics of vulnerability. Entitlements and panarchy can be coupled by first assessing the extent to which communities depend on the natural environment for livelihoods, and the options available if the environment changes. Once a dependency on the environment has been ascertained, the characteristics of the specific ecosystems in question must then be assessed to determine their vulnerability to external shocks and disturbances. The panarchy framework makes this possible.

\section{INTRODUCTION}

Between 1845 and 1850, famine, pestilence, and death descended on Ireland. Approximately two million people lost their lives, families, or homes during these years, and the population has never since reached its pre-famine level (Allen Figgis Publishers 1968). This tidal wave of human suffering began in September 1845 , when a disease caused by the fungal pathogen Phytophthora infestans was observed in the potato crop. Field after field fell prey to this rot and, very shortly, the 1845 yield, on which a vast proportion of the country depended, vanished. The blight returned in 1846. Although the following year saw a reprieve, the people did not have sufficient seed potatoes to plant, and the blight reappeared in 1848, 1849, and 1850. By the time it subsided, Phytophthora infestans left a path of destruction and human misery that changed Ireland forever.
Aside from the historical and cultural significance of this event, the Irish Potato Famine provides a stark example of a collision between human society and environmental conditions. It illustrates how social and economic forces made the population dependent on the potato and vulnerable to anything that disrupted this one crop. It also illustrates how agricultural management made the potato crop itself vulnerable to a pest outbreak. Looked at in this way, the famine is a case study that can contribute to the on-going academic debate on the relationship between society and the environment.

Over the past decade, academics have struggled to articulate the ways in which society and the environment are linked (Taylor and Buttle 1992, von Storch and Stehr 1997, Ohlsson 2000, Kasperson et al. 2001, Dalby 2002, Fraser et al. 2003). One challenge has been that cumulative effects and complex causal 
chains bring unpredictable surprises. For example, Ireland had experienced outbreaks of the blight many times in the $17^{\text {th }}$ and early $18^{\text {th }}$ centuries. In 1845 , however, social and ecological conditions created a situation that allowed this relatively common agricultural pest to destroy an entire society. Countless examples like the Irish Potato Famine (the effect of climate change on agriculture, the elusive relationship between resource scarcity and conflict in the Middle East or Africa, and the cumulative and long-range effect of pollutants in Canada's Arctic) have forced scholars to abandon simplistic or deterministic theories about how the environment affects society (HomerDixon 1999, Muscara 2000, Griffin et al. 2001, Intergovernmental Panel on Climate Change 2001, Dalby 2002).

This has left an intellectual void, and some scientists argue that new thinking is needed to develop an analytical framework to articulate, describe, and understand the reflexive relationship between humans and the environment (Kasperson et al. 1995, 2001, Smith 2001). The challenge is to combine social and environmental data in meaningful ways, which respect the differences between these types of systems and allow for more complexity (Bar-Yam 1992, Kauffman 1995). In light of this complexity, the purpose of this paper is to build a method for assessing ecological and social vulnerability and to link these concepts together using the Irish Potato Famine as a case study. Specifically, I will explore Amartya Sen's idea of food "Entitlements", a conceptual framework for understanding food security (Sen 1980). The entitlement framework is valuable because it provides insight into the extent to which some communities depend on the natural environment for subsistence and characterizes those communities that have the ability to find alternatives if their food supply is disrupted. Understanding which communities depend on the environment, however, does not provide any insight into the environment itself or the extent to which the environment is vulnerable to disturbance. To address this, I propose using Gunderson and Holling's (2002) "Panarchy" framework to help illustrate the characteristics of ecological systems that are vulnerable to external shocks. I propose combining these two frameworks to create a single integrated approach to studying vulnerability, society, and the environment.

\section{FOOD ENTITLEMENTS}

Nobel prize-winning economist, A.K. Sen (1980) argued that, to understand vulnerability, it is necessary to assess all the various channels that a community can use to obtain food. Sen dubbed these channels "entitlements." The failure to obtain food, therefore, becomes an "entitlement failure" and may occur anywhere between the producers and the consumers of food (Dreze and Sen 1989). There are three basic forms of entitlement: food can come from either a direct entitlement (when a family grows its own food), an indirect entitlement (when a family uses income to purchase food), or a transfer entitlement (when a family obtains food charity). Acute malnutrition and famine occur when the entitlement of a person or a community is disrupted and they cannot switch to another method of obtaining sustenance. This can be an indirect or demand-side failure, which occurs when people lose their purchasing power through unemployment, falling wages, rising food prices, or inflation and do not have the assets to either grow their own food or there is no accessible food-aid program. Alternatively, a population may experience a direct entitlement failure when a crop fails and there is a shortage in the supply of food. Sen (1980), however, cautions that, in a market situation, where many crops are grown for sale, crop failure may not create a failure of supply (at a local level), but of demand when people lose their incomes.

The entitlement framework is useful because it disaggregates the reasons why a person or group may become vulnerable to hunger (Chisholm and Tyers 1982). For example, traditionally, the Irish Potato Famine was viewed as a Malthusian apocalypse, where population growth surpassed food production and led to a collapse (in Daly 1986, O'Grada 1989). Alternatively, the famine has been blamed on the British government's laissez-faire policies (WoodhamSmith 1962). George Bernard Shaw's Man and Superman sums up this sentiment:

Malone: Me father died of the starvation in the Black 47...

Violet: The Famine?

Malone: No, the Starvation. When a country is full of food and exporting it [to Britain], there can be no famine....(Shaw 1911, p. 196.)

Approaching the famine from Sen's perspective, allows a greater degree of insight and, on the eve of the famine, it reveals a society that had lost many of its entitlements. 
Prior to the famine, indirect entitlementsopportunities to raise income - declined for large parts of the Irish population. The massive industrial expansion in England made local cottage industries in Ireland unviable (Mokyr 1987). Between 1821 and 1841 , the number of people involved in Irish industry shrank from 40 to $30 \%$ of the total population. Between 1825 and 1840, the linen industry in the town of Bandon dropped from roughly 2000 private, selfemployed weavers to fewer than 100 (Foster 1988). This loss of non-agricultural income was exacerbated by a shift in land management. With the fall of Napoleon in 1815, the price for grain fell, and it became uneconomical for landlords to maintain large areas of labor-intensive grain agriculture. Combined with a sharp increase in demand for livestock products, landlords evicted tenants, raised rents, and changed cultivated fields into more profitable pastures (Foster 1988). This reduced entitlements because livestock production, unlike tillage agriculture, requires a major capital investment, so small farmers had no chance to participate in the livestock market.

The loss of indirect entitlements resulted in an increased dependence on direct entitlements (subsistence agriculture). Although this is not necessarily problematic, it coincided with other demographic pressures to increase the vulnerability of the Irish population. Estimates suggest that, thanks to such traditions as dividing farms equally among all sons as they reached maturity (allowing for early marriage and large families), the population of Ireland grew an average of $1.3 \%$ a year before the famine, rising from 2.2 million in 1600 to somewhat more than 8 million (Daly 1986, Kinealy 1994). Population growth, along with the shift from grain to pasture agriculture that took land out of cultivation, meant that, by the 1840 s, there were 700 people per square mile of arable land (Daly 1986, O'Grada 1989). In order to adapt to these changes, Irish peasants altered their diet. At the beginning of the $19^{\text {th }}$ century, most people existed on a varied diet that included grain, vegetables, and animal protein. Potatoes were usually fed to animals, or used to stave off hunger if cereal crops failed and there was no money to buy food (Bourke 1993). By 1845, however, much of the country, especially in the west, had switched over entirely to potato subsistence. This is because, compared with other crops, the potato is a remarkably efficient source of human nutrition; a hectare of land could feed an average of 5.14 people on wheat or 10.32 people on potatoes (O'Grada 1989). However, although the varieties of potatoes grown were highly productive, often they would not store for an entire year and many people went hungry every summer, between the time when the last year's crop was no longer fit to eat, and the new crop was ready. Thus, the economic situation had degenerated to such an extent that about 3 million people were dependent on single variety of food that never provided adequate nutrition for the year. This situation accentuated the differences between social classes. A well-established farming family would have been unaffected by the seasonal hunger, and would also have been in a position to sell their surplus to the peasants whose potatoes did not sustain them. Each year, therefore, peasants fell further and further into debt (Foster 1988).

The loss of direct and indirect entitlements was made worse by geographic and economic isolation which prevented people from obtaining food aid (Sen calls these "transfer entitlements"). Although the British government provided some famine relief, mostly by selling low-priced grain to the Irish market and by employing people on public works projects $(750,000$ people were employed at the height of the famine in 1847), the people who needed the help most were least able to access these programs. They were both too far away from the areas where relief projects were established and not sufficiently integrated into the cash economy to be able to purchase low-priced grain (Lynch and Vaizey 1960).

Therefore, the situation in Ireland leading up to the famine can be characterized as a society slowly losing food entitlement options. The English Industrial Revolution and a shift in agricultural management practices made it impossible for large parts of the population to participate in the cash economy. This constituted a loss of indirect entitlements. Population growth and landlords evicting peasants to make room for livestock meant increased rural congestion affected direct entitlements by forcing families to exist on very small landholdings. Economic and geographic isolation meant that transfer entitlements were unavailable to the most vulnerable members of society. This made subsistence agriculture, based around the potato, the only viable way that poor members of this society could obtain food entitlements.

The entitlement framework provides insight into the characteristics of communities dependent on the environment and vulnerable to change. This assessment, however, does not provide insight into environmental conditions themselves. Many 
subsistence agricultural communities and huntergatherer societies have flourished despite having few entitlement options. So, although entitlement theory helps explore some of the social causes of vulnerability, it is still necessary to develop tools that characterize ecosystems vulnerable to disturbance.

\section{PANARCHY AND ADAPTIVE CYCLES}

The "Panarchy" framework proposed by Gunderson and Holling (2002) holds that all ecosystems cycle through periods of resource accumulation and collapse based on three key characteristics: the resilience of the ecosystem, the connectedness of individuals in the ecosystem, and the potential for change in the ecosystem. The first two characteristics, resilience and connectedness, are relatively simple concepts. Gunderson and Holling (2002) define resilience as the adaptive capacity of an ecosystem, which can be measured as the diversity in that system. Diverse systems are better able to tolerate a wide range of environmental conditions and disturbances than are simple systems, which are vulnerable to disturbances (Benbrook 1990, Mannion 1995, Gliessman 1998, Altieri 1999). Connectedness is an assessment of whether individuals in the ecosystem are closely crowded together over both space and time. This provides an indication of the degree to which a system can be controlled by external forces. A dense forest would have more connectivity and be more vulnerable to external forces than a loosely stocked plantation.

The potential for change in the ecosystem is a slightly more complicated concept. Gunderson and Holling (2002) loosely define potential as the wealth available in an ecosystem, as wealth determines the range of future options. From an ecological perspective, wealth can be measured in terms of the foliage that would provide food for an opportunistic pest, or biomass that could fuel a fire. For example, in a forest ecosystem, a rich foliage or high biomass would represent a wealthy system with a high potential for change. Used in this way, a wealthy system is more liable to be affected by a disturbance than a non-wealthy system.

Gunderson and Holling (2002) observe that, after a disturbance, an ecosystem accumulates biomass, thereby increasing the wealth available in the system and the potential for change. As this happens, new species fill available ecological niches and connectivity increases. Simultaneously, more competitive species out compete less successful species, and diversity dwindles. As ecosystems move through this process, they reach a point when the potential for change is high, connectivity is high, and resilience is low, becoming "....accidents waiting to happen" (Holling 2001, p. 396). At this stage, a system is vulnerable to disturbances and external shocks, such as pest outbreaks. A disturbance then releases accumulated resources and returns the system to a state of higher diversity, less connectivity, and less wealth.

Many of the characteristics of the agro-ecosystem in Ireland in the decades leading up to the famine conform to the trajectory described by panarchy. We can assess the resilience of the Irish agricultural landscape in terms of crop diversity. As already discussed, the agro-ecosystem in Ireland progressed from a relatively complex system of mixed livestock, grain, and potato production to a system that was wholly based on the potato. This offered no opportunities for crop rotation, which even today is essential to keep pests out of potato crops worldwide (Hajer 1999, Scholte 1992,Umaerus 1992). Peasants not only switched from grain to potatoes, but also further specialized in only those varieties of potato that maximized productivity, even at the expense of pest resistance, storability, and palatability. For example, the Black potato was used extensively in the 1700s and was reported to be the first "outstanding variety" of potato because it kept throughout the year and "...its pulp affords a strong invigorating diet to the labourer..." (in Bourke 1993, p. 32). The Apple, which was first described in the 1770s, was also highly praised, despite not being particularly productive. The Cup, which was widespread in the first decades of the 1800 s, was notable only for productivity and its ability to grow in adverse conditions as, "[the Cup was] more productive, but very inferior in every other quality [to the apple]..." (in Bourke 1993, p. 34). The Lumper, however, was by far the most common variety grown in Ireland just before the famine. A report from the time describes the Lumper as:

...a species of potato...[that]...has been
brought into general cultivation, on
account of its great productiveness, and
the facility with which it can be raised
from an inferior soil and with a
comparatively small portion of manure.
The root, at its first introduction, was
scarcely considered food enough for
swine; it neither possesses the farinaceous
qualities of the better varieties of the
plant, nor is it as palatable as any other,
being wet and tasteless, and in point of
substantial nutriment, little better as an


article of human food, than a Swedish turnip. (Drummond Report 1838, in Bourke 1993, p. 43.)

We can also infer that the connectivity of the Irish agricultural landscape increased as the famine approached by considering the already-cited figures on rural population density. In the decades following the Napoleonic war, individual farms in Ireland became more and more connected as a single ecological system. Thanks to rural congestion, which forced families to exist on small parcels of land, fragmented landholdings, and population growth, farms moved closer together, fields were tightly packed together, and the distance between potato fields shrank. This meant that, once established, the blight was able to spread quickly through the entire countryside and quickly devastate huge areas.

Finally, from the perspective of the organism that caused the blight, these tightly packed potato fields represented a very wealthy system, full of resources that could support a massive, virulent, and devastating outbreak of this disease.

In light of wealth, connectivity, and diversity, the agro-ecosystem in Ireland leading up to the famine follows the same trajectory as proposed in the panarchy model. It moved from a state of low connectivity to high connectivity, low wealth to high wealth, and diversity to specialization. In doing so, it became vulnerable to a trigger or disturbance such as the potato blight.

After the blight, the Irish landscape was totally changed. The system was, from an ecological perspective, much less wealthy: between 1851 and 1911, the amount of cultivated land fell by approximately $50 \%$, from 1.9 to 0.8 million hectares. This land was either abandoned or converted into pasture (Whelan 1997). The landscape also became much less connected: according to the 1841 and 1851 censuses, on the eve of the famine, there were close to 700000 farms, almost $50 \%$ of which were less than 5 ha in area. In 1851, just 10 years later, there were roughly 580000 farms, $50 \%$ of which were greater than 15 ha. This decline mostly affected small farms, and the number of farms under 5 ha fell from over 300 000 to under 100000 . From this we can also infer that the landscape became much more ecologically diverse, as small intensive potato fields and dense rural populations gave way to an extensive pasture system with a much smaller human population. This precipitated a massive change in Irish culture. The Irish population, which had grown from an estimated 2 million souls in the 1600 s to 8 million in 1841 , steadily declined following the famine, falling below 3 million in the 1960s. Since then, it has grown to roughly 4 million people (Irish Centre for Migration Studies 2003). The Irish language, already in decline before the $1840 \mathrm{~s}$, continued disappearing, and the tradition of subdividing farms equally among all sons also ceased in most regions. The result of the famine was to precipitate a watershed in Irish history. Many communities that had depended on subsistance agriculture vanished as people immigrated to the New World and the economy shifted gradually toward urban industry.

A regional breakdown of emigration rates in the decades following the famine provides a suggestive insight into the way the people recovered after the famine. Emigration, which had become a fact of life in Ireland in the $1830 \mathrm{~s}$, took off during the famine years, when close to 1 million people relocated to Britain and America. Up to 1881, however, emigration in the province of Connaught was only two-thirds the national average. This is surprising as Connaught was the most poverty-stricken region and the one hardest hit by the famine. The explanation seems to be that poverty was so severe there that the people could not afford to leave and were thus forced to survive on their wasted lands (Lee 1977). In 1881, partly because of a minor increase in prosperity, and largely because of remittances from the United States, the emigration rate in Connaught began to catch up with the rest of the country and, in 1891, it was one and a half times the national average, a trend which remained characteristic of this province until the mid $20^{\text {th }}$ century (Lee 1977).

\section{SYNTHESIS}

Both panarchy and the entitlement framework provide insight into different aspects of human vulnerability in terms of food security. Assessing food entitlements allows us to better understand how community food security may become vulnerable over time as different social and economic forces eliminate or restrict avenues to obtain food. Panarchy provides a way of characterizing whether or not ecological systems are vulnerable to disruption. Neither framework, however, provides an adequate way of examining the totality of human-environmental relationships. Panarchy remains a model applicable to ecological systems, and entitlement deals strictly with socio-economic relations. 
For example, although the ecological characteristics of the pre-famine agricultural system can be characterized as wealthy, connected, and non-diverse, the social characteristics are different. The communities hardest hit were poor, which is the opposite of what panarchy suggests is typical of vulnerable systems. Acknowledging this, various chapters in the book Panarchy edited by Gunderson and Holling (2002) suggest that, under certain circumstances, poverty (not wealth) creates vulnerability in human systems (Holling 2000, Gunderson et al. 2002, Gunderson and Holling 2002, Holling et al. 2002a, 2002b). However, with the exception of a brief note by Berkes and Folke (2002), little work has been done to understand under which conditions a poverty trap exists and to what extent the panarchy model provides useful insights. For example, it is difficult to see how panarchy explains the plight of Irish cottiers who had lost their income due to industrial restructuring. The entitlement framework is a more appropriate way of understanding this predicament.

Similarly, the communities that were worst affected by the famine, were economically isolated, and not tightly connected as would be expected by Gunderson and Holling's model. Some scholars suggest that the Irish agricultural system prior to the famine had two distinct components, more or less divided along geographic lines: a traditional subsistence system in the west, where the famine was harshest, and a modern industrial market system centered around Ulster in the north, where the effects of the famine were relatively light (Lynch and Vaisey 1960). According to this interpretation, large parts of Ireland's population were beyond the monetary system because:

The potato, not money, was the basic factor by which the value of labour was determined. Farmers and landlords gave their labourers a cabin and a piece of potato ground.... Rent, in each case was worked off in days of labour...these wages were not given in money into the labourer's hand, but set off against his rent.... The real reward was the patch of potato ground. (Woodham-Smith 1962.)

To test the claim that the famine hit non-monetarized areas harder, Mokyr (1987) compared how respondents in different counties answered two key questions from the 1841 census: (1) "are wages of labour paid in money, or provisions, or by conacres [a rental agreement whereby labor was exchanged for the right to cultivate a patch of land on a yearly basis] or in what other way?" and (2) "upon what conditions, exclusive of that, do labourers or cottiers hold their cabins and land? Is it usual to require duty labour, in addition to, or in lieu of rent?" (Great Britain 183b Vols XXXI and XXXII in Mokyr 1987). His results support the conclusion that western Ireland was more isolated from the money system than northern Ireland and, although there was not a clearcut regional difference as some suppose, if barter was used, it was mainly in the regions where the famine's toll was highest. These data suggest that economic and social isolation, and not connectivity are important characteristics of social vulnerability.

Both ecological and social systems, however, were simple systems, lacking resilience and diversity. This suggests that, although an ecologically fragile system may be characterized as simple, wealthy, and connected, socially vulnerable systems may be simple, poor, and isolated.

On the other hand, although the panarchy model needs refinement to address social issues, the entitlement framework does not have an adequate mechanism for including the role of the environment. To address this lacuna, Watts and Bohle (1993) propose analyzing vulnerability, which they define as the outcome between environmental and socio-economic forces. Specifically, Watts and Bohle are interested in the types of shocks or stresses that communities are exposed to and the methods they employ to cope. Other scholars propose that resource-dependent communities use an "environmental entitlement" just as they access the direct and indirect entitlements proposed by Sen (Mearns 1996). This approach focuses on the rights and resources people have access to and how they can use these rights and resources to enhance well-being (Leach et al. 1999). Although this approach has many merits, in that it helps highlight the role of institutions vis à vis the environment (Post and Snel 2003), it reduces the environment to a static and unchanging resource base and ignores the fact that precipitation variation, pest outbreaks, and temperature extremes may cause a resource-plenty environment to become impoverished very quickly. Environmental entitlements, therefore, do not help us assess whether agricultural practices themselves contribute to increased or decreased food insecurity.

By combining a socially driven framework such as that of entitlements with panarchy, a tool of landscape ecology, we obtain new ways of exploring both the 
social and environmental characteristics of vulnerability. Entitlements and panarchy can be coupled by first assessing the extent to which communities depend on the natural environment for livelihoods, and the entitlement options available to a community if the environment changes. Once a dependency on the environment has been ascertained, it is then necessary to assess the wealth, connectivity, and resilience of the specific ecosystems in question to determine their vulnerability to external shocks and disturbances.

Combining these two approaches emphasizes the twoway interaction between social and ecological vulnerability. In Ireland, the forces that led to socioeconomic isolation and poverty also led to the simplification of the Irish agricultural system. One can only imagine that subsisting on small, inadequate, and marginal fields of potatoes was a survival strategy born out of desperation as industrial restructuring, changes in the price for agricultural commodities, and population pressures made any alternative unviable. This means that broader socio-economic conditions affected both social and ecological vulnerability by economically marginalizing populations and creating the conditions whereby an entire population depended on an ecologically fragile system that was based on a single cultivar.

At least one clear gap remains in this analysis that must be addressed. Culture, as an informal set of norms and standards, may have a serious effect on vulnerability. For example, the tradition of subdividing land among all sons was a cultural practice that undermined the Irish agricultural system and helped foster unusually large families (especially compared with the rest of $18^{\text {th }}$ century Europe). Similarly, it is impossible to separate the high birth rate of the time from the influence of the Catholic Church. Neither of these two factors would be assessed using the entitlement or panarchy frameworks. Indeed, one of the chief criticisms of the entitlement framework is that it does not provide for an assessment of how social institutions may affect food security (Post and Snel 2003). Homer-Dixon (1995) addresses this through a methodology he calls "process tracing" that helps researchers construct webs or networks of causal relationships that link social and environmental variables. This approach is uncommon in the natural sciences, where scholars often separate dependent and independent variables and use statistical methods to assess correlation. Studying entitlements using an approach based on process tracing, which finds its roots in anthropological methods such as ethnography, allows a researcher to differentiate between different causes of vulnerability, and the role that culture plays. This involves a careful and rich study of a region, using methods such as "...establishing rapport, selecting informants, transcribing texts, taking genealogies, mapping fields, keeping a diary..." (Geertz 1973, p. 6).

\section{CONCLUSION}

This paper uses the Irish Potato Famine to illustrate how environmental change can result in vulnerability in human populations and how contemporary theories can provide insight into these types of situations. Together, the entitlement framework and panarchy offer useful explanatory models that explain why the population was dependent on the potato and how the potato crop itself was vulnerable. First, the entitlement framework allows researchers to assess the degree to which a community's livelihoods depend on ecological systems. For example, a social and economic transformation in Ireland forced the Irish peasantry to adapt to a situation where they had few food entitlements. This meant that communities had limited opportunities to participate in the market economy, and had few choices in the types of crops that would support rural population densities. The response, which was born out of poverty, was to depend on the potato. Although the entitlement framework illuminates some of the reasons why communities depend on ecological systems, it does not help us understand situations where ecological systems themselves are vulnerable and might crash.

Thus, we turn to panarchy, which characterizes ecological cycles of accumulation and collapse based on the wealth, connectivity, and diversity of ecosystems. In the famine, social conditions created an agro-ecological system that was marked by a high degree of connectivity, a low degree of resilience, and (from an ecological perspective) a large amount of wealth. As these are all the characteristics of a system about to enter a period of instability, we may conclude that the Irish peasantry was dependent on a single food entitlement that was derived from an ecological system that was itself very vulnerable.

It is possible to link these two concepts by first assessing the extent to which community livelihoods depend on the environment, and then by assessing the vulnerability of the environment itself to shocks and disturbances. Therefore, whenever communities are 
found to depend on ecological systems to obtain livelihoods, it would be necessary to evaluate the connectivity, wealth, and diversity of these ecological systems. By doing so, this should make a modest contribution toward linking ecological and social systems into a single analytic framework that uncovers some of the roots of vulnerability in marginal communities.

Responses to this article can be read online at: http://www.consecol.org/vol7/iss2/art9/responses/index.html

\section{Acknowledgments:}

I would like to thank Olav Slaymaker, and Warren Mabee for continued and on-going discussions on the interaction of social and environmental factors in determining vulnerability. I would also like to thank David Fraser and David Wilson for editing and commenting on much earlier drafts of this paper.

\section{LITERATURE CITED}

Allen Figgis Publishers, editor. 1968. Encyclopaedia of Ireland. Allen Figgis Publishers, Dublin, Ireland.

Altieri, M. 1999. The ecological role of biodiversity in agroecosystems. Agriculture, Ecosystems and the Environment 74: 19-31.

Bar-Yam, Y. 1992. Dynamics of Complex Systems. AdisonWesley, Reading, UK.

Benbrook, C. 1990. Society's stake in sustainable agriculture. Pages 68-76 in C. Edwards, R. Lal, P. Madden, and R. Miller, editors. Sustainable agriculture systems. Soil and Water Conservation Society, Ankeny, Iowa, USA.

Berkes, F., and C. Folke. 2002. The Hindu cast system and the hierarchy trap. Pages 97-98 in L. Gunderson and C. Holling, editors. Panarchy: understanding transformations in human and natural systems. Island Press, Washington, D.C., USA.

Bourke, A. 1993. The Visitation of God? The Potato and the Great Irish Famine. Lilliput Press, Dublin, Ireland.

Chisholm, A., and R. Tyers. 1982. Food Security: Theory, Policy and Perspectives from Asia and the Pacific Rim. Lexington Books, Toronto, Ontario, Canada.

Dalby, S. 2002. Environmental Security. University of Minnesota, Minneapolis, Minnesota, USA.
Daly, M. 1986. The Famine in Ireland. Dublin Historical Association, Dublin, Ireland.

Dreze, J., and A. Sen. 1989. Hunger and Public Action. Claredon Press, Oxford, UK.

Foster, R. 1988. Modern Ireland. Penguin Books, New York, New York, USA.

Fraser, E., W. Mabee, and O. Slaymaker. 2003. Mutual dependence, mutual vulnerability: the reflexive relation between society and the environment. Global Environmental Change In Press.

Geertz, C. 1973. The Interpretation of Cultures; Selected Essays. Basic Books, New York, New York, USA.

Gliessman, S. 1998. Agroecology. Chelsea, Ann Arbor Press, Ann Arbor, Michigan, USA.

Griffin, D., C. Kellog, and E. Shinn. 2001. Dust in the wind: long range transport of dust in the atmosphere and its implications for global public and ecosystem health. Global Change \& Human Health 2:20-34.

Gunderson, L., C. Holling, and G. Peterson. 2002. Surprises and sustainability: cycles of renewal in the Everglades. Pages 315-332 in L. Gunderson and C. Holling, editors. Panarchy: understanding transformations in human and natural systems. Island Press, Washington, D.C., USA.

Gunderson, L., and C. S. Holling. 2002. Panarchy: Understanding Transformations in Human and Natural Systems. Island Press, Washington, D.C., USA.

Hajer, M. P. 1999. Punishment for mistakes in late blight control: an interview with Dr Huub Schepers. World Potato Congress. (Online.) http://www.potatocongress.org/sub.cfm?source=145.

Holling, C. 2000. Theories for sustainable futures. Conservation Ecology 4(2):7. (Online.) URL: http://www.consecol.org/vol4/iss2/art7/index.html.

Holling, C. 2001. Understanding the complexity of economic, ecological, and social systems. Ecosystems 4:390-405.

Holling, C., S. Carpenter, W. Brock, and L. Gunderson. 2002a. Discoveries for sustainable futures. Pages 395-418 in L. Gunderson and C. Holling, editors. Panarchy: understanding transformations in human and natural systems. Island Press, Washington, D.C., USA.

Holling, C., L. Gunderson, and G. Peterson. 2002b. Sustainability and panarchies. Pages 63-103 in L. Gunderson and C. Holling, editors. Panarchy: understanding transformation in human and natural systems. Island Press, Washington, D.C., USA.

Homer-Dixon, T. 1995. Strategies for Studying Causation in Complex Ecological Political Systems. American 
Association for the Advancement of Science and the University of Toronto, Washington D.C., USA and Toronto, Ontario, Canada. (Online.) URL: http://www.library.utoronto.ca/pcs/eps/method/methods 1.htm.

Homer-Dixon, T. 1999. Environment, Scarcity and Violence. Princeton University Press, Princeton, New Jersey, USA.

Intergovernmental Panel on Climate Change. 2001. Working Group 1 Climate Change 2001: The Scientific Basis. IPCC, Paris, France.

Irish Centre for Migration Studies. 2003. The Population of Ireland. University College Cork, Cork, Ireland. (Online.) URL: http://migration.ucc.ie/daonscoil/charts.htm.

Kasperson, J., R. Kasperson, and B. Turner. 1995. Regions at Risk. United Nations University Press, Tokyo, Japan.

Kasperson, R., J. Kapserson, and K. Dow. 2001. Global environmental risk and society. Pages 1-48 in J. Kasperson and R. Kasperson, editors. Global environmental risk. United Nations University Press, Tokyo, Japan.

Kauffman, S. 1995. At Home in the Universe: the Search for Laws of Self-organization and Complexity. Oxford University Press, New York, New York, USA.

Kinealy, C. 1994. The Great Calamity. Gill and MacMillan, Dublin, Ireland.

Leach, M., R. Mearns, and I. Scoones. 1999. Environmental entitlements: dynamics and institutions in community-based natural resource management. World Development 27:225-247.

Lee, R. 1977. The Modernization of Irish Society. Gill and MacMillan, London, UK.

Lynch, P., and J. Vaizey. 1960. Guinness's Brewery in the Irish Economy 1759-1876. Cambridge University Press, Cambridge, UK.

Mannion, A. 1995. Agriculture and Environmental Change. John Wiley and Sons, Toronto, Ontario, Canada

Mearns, R. 1996. Environmental entitlements: pastoral natural resource management in Mongolia. Cahiers des Sciences Humaines 32:105-131.

Mokyr, J. 1987. Why Ireland Starved. George Allen and Unwin, London, UK.

Muscara, L. 2000. Gottmann's geographic glossa. GeoJournal 52:285-293.

O'Grada, C. 1989. The Great Irish Famine. MacMillan, London, UK.

Ohlsson, L. 2000. Livelihood Conflicts-Linking Poverty and Environment as Causes of Conflict. SE-105 25, Environmental Policy Unit, Sida, Stockholm, Sweden.

Post, J., and M. Snel. 2003. The impact of decentralised forest management on charcoal production practices in Eastern Senegal. Geoforum 34:85-98.

Scholte, K. 1992. Effect of crop rotation on the incidence of soil-borne fungal diseases of potato. Netherlands Journal of Plant Pathology Supplement 2:93-102.

Sen, A. 1980. Poverty and Famines. Claredon Press, Oxford, UK.

Shaw, G. 1911. Man and Superman. Constable, London, UK.

Smith, K. 2001. The risk transition in developing countries. Pages 148-1172 in J. Kasperson and R. Kasperson, editors. Global environmental risk. United Nations University Press, Tokyo, Japan.

Taylor, O., and F. Buttle. 1992. How do we know we have global environmental problems? Science and the globalization of environmental discourse. Geoforum 23:405-416.

Umaerus, V. 1992. Crop rotation in relation to crop protection. Netherlands Journal of Plant Pathology Supplement 2:241-249.

Watts, M. J. and Bohle, H. 1993. The space of vulnerability: the causal structure of hunger and famine. Progress in Human Geography 17:43-67.

von Storch, H., and N. Stehr. 1997. The case for the social sciences in climate research. Ambio 26:66-71.

Whelan, K. 1997. The Atlas of the Irish Rural Landscape. Cork University Press, Cork, Ireland.

Woodham-Smith, C. 1962. The Great Hunger. Penguin Books, London, UK. 